\title{
Effect of regional factor productivity on manufacturing sector: The case of Sino-Pak economic ties
}

\author{
Muhammad Imran ${ }^{1 *}$ (D, An HuSen ${ }^{2}$, Muhammad Kaleem ${ }^{3}$, Arshad Khan Bangash ${ }^{3}$, Nizam Ud Din ${ }^{4}$ and Sobia ${ }^{5}$
}

\author{
* Correspondence: imranecon@ \\ bkuc.edu.pk \\ ${ }^{1}$ Department of Economics, Bacha \\ Khan University, Charsadda, Pakistan \\ Full list of author information is \\ available at the end of the article
}

\begin{abstract}
Introduction: Economic ties and trade blocs increase the flow of trade between participating countries and lead to different levels of economic and structural changes.

Case description: This paper focuses on the structure of industrial value-added between China and Pakistan, as the two countries recently launched the CPEC (China-Pakistan Economic Corridor) project.

Discussion and evaluation: This study utilizes panel data from 1995 to 2015 to test certain factor effects on regional value-added through econometric analyses. The results show that each country has its own economic growth rate and market size that respond differently to industrial value-added production.

Conclusion: Aggregate factor productivity at China is higher than in Pakistan but growth in factor productivity in the latter is higher than the former; similarly, the share of bilateral trade is higher in the case of Pakistan. Although each country responds differently to the new economic ties, the macroeconomic results support bilateral economic ties between them.
\end{abstract}

Keywords: New economic geography, China-Pakistan economic-ties, Factor productivities

JEL codes: P25, R11, R12, F21

\section{Introduction}

The idea of globalization has led many countries to form economic and strategic blocs, such as the European Union (EU), Organization for Economic Cooperation and Development (OECD), and the North American Free Trade Agreement (NAFTA), which resulted in the higher flow of goods and people between the member countries and aggregately increased the pace of economic activities. Recently, Baldwin and Okubo (2009) contended that the flow of trade transactions can be accelerated through either (i) infrastructure facilitation, by improving transportation and communication, or (ii) varying trade tariffs, including subsidies and trade regulations. Consequently, these financial and nonfinancial measures have a significant impact on market access and the location of economic activities.

Investment in infrastructure facilitation is considered to be one of the financial determinant of economic development, as improving intraregional and interregional

(c) The Author(s). 2020 Open Access This article is distributed under the terms of the Creative Commons Attribution 4.0 International License (http://creativecommons.org/licenses/by/4.0/), which permits unrestricted use, distribution, and reproduction in any medium, provided you give appropriate credit to the original author(s) and the source, provide a link to the Creative Commons license, and indicate if changes were made. 
transportation and communication facilities increases the level of market access. Furthermore, regional economic cooperation and trade treaties between different countries and regions (as nonfinancial measures) are more beneficial for the participant countries to extend regional market size. In particular, economic cooperation and trademotivating treaties result in increased trade liberalization between the member countries, which further leads to a larger market. Fujita et al. (1999) and Fujita and Thisse (2002) pointed out that decreasing trade costs provides a stimulus to the supply of value-added that will increase regional market size. Furthermore, according to Combes et al. (2008), Ottaviano et al. (2002) and Murata (2007), larger markets produce valueadded at comparatively lower prices, which, combined with other social amenities, results in increased migration to the specific region (see Delgado et al. 2010; Pekkala 2002). Hanson(2005) studied US counties and found strong evidence that consumer demand is more confined to markets with lower prices or higher wages, which is the ultimate source of labor migration to the specific region. The above observations have been confirmed by Brakman et al. (2012) and their research further points out that the size of the market is positively affected by the domestic wage ratio; Ellison et al. (2010) observed similar results for German regions.

Similarly, the extension of market size, by both measures, attracts manufacturers to the region in question and raises the level of labor productivity through the spillover effect (Redding and Venables 2004). The spillover effect, according to Duranton and Puga (2004), is more beneficial for manufacturers to form agglomerations. Using the Krugman (1991) model of new economic geography (NEG) in multiple regions, Behrens et al. (2009) found that the home market effect ${ }^{1}$ of regional market access, market size, and market competition governs the location decisions of industrial value-added production. Furthermore, they extended their findings to assess the effect of geographical location of a region, regional consumer behavior, and the number of vertical industries on the location decision by the industrial value-added producers.

As mentioned previously, regional market access can be improved by improving infrastructure, whereas some countries prefer to have economic ties to the bordering countries. Such ties not only provide new markets for domestic production but also increase flow of trade between the member countries at comparatively lower prices. Hanson and Song (1998), in their study of NAFTA (US-Mexican ties), found that increasing regional economic integration caused a decline in trade costs and attracted Mexican manufacturers and labor to larger US markets. Davis and Weinstein (2003) obtained the same results for OECD countries, where the "home market effect" and regional trade costs attract different manufacturers.

Similarly, the Chinese government's policy of One Belt One Road (OBOR) is an initiative to combine Eurasian markets in such a way that every participant country can equally share the economic benefits. Imran et al. (2017) presented a detailed case of Chinese provincial industrial distribution and pointed out that according to recent Chinese government policy, China is trying to redistribute their economic activities from the northeast to the northwest and for that reason, OBOR could be

\footnotetext{
1"Home market" represents the market situation after relaxing trade barriers or giving preferential trade agreements to member countries and form a multinational big "home" market.
} 
the source of equalization inside China. Meanwhile, the China-Pakistan Economic Corridor (CPEC) provides an opening (in northwest China) for the OBOR to connect to the warm-water ports of the Gwadar coastal region in southwest Pakistan. The infrastructure that connect these regions include highways, railways, and pipelines to transport oil, gas, and passengers over a distance of $3000 \mathrm{~km}$ from Gwadar to the Kashgar region. Plans for the CPEC include the construction of Gwadar port and its related railroad links to Chinese markets and, further, to the Central Asian countries, while providing easy access to Middle-East regions and bypassing the Strait of Malacca, which is currently China's main trade route Marc (2008). Apart from transportation and significant infrastructure investments, the CPEC will supplement telecommunications and boost the energy sector to fulfill the domestic power consumption needs. Thus, according to Saqib et al, (2015) this so-called "game and fate changer" project will transform Pakistan's economy and position it as an Asian economic hub, with the region's location proving ideal for future industrial clustering and agglomeration. Furthermore, it will boost the economic and strategic ties between Pakistan and China.

This paper focuses on a comparative analyses of both countries and their economies by assessing the value-added shares of manufacturing sectors and productivity shares of labor and capital. The upcoming sections are organized as follows. Section 2 presents the model used to demonstrate the effect of market size and factor productivities effect on value-added production of manufacturing sector. Section 3 provides a detailed picture of the economic structure of China and Pakistan with specific figures and regression results. Sections 4 and 5 present the concluding remarks and recommendation, respectively.

\section{Model}

This paper examines the effects of the bilateral economic relationship between China and Pakistan on their economic structure and factor productivities. Empirically, this paper develops a suitable model to help both nations decide their possible economic structure and sectors whose productivity is to be boosted. And as our study is confined to the case of two countries, our sample is small, and a common autocorrelation-parameter is thus reasonable, following the approximately equal individual panel-specific correlations. Therefore, the assumption of common autocorrelation parameters will allow us to use more information while estimating the autocorrelationparameter, in order to produce more reasonable estimates of the regression coefficients. To account for the abovementioned issues, this study utilizes the Generalized Linear Regression (GLS) model with heteroscedasticity and cross-sectional correlation..

The model assumes that each new firm has $i(i=1 \ldots . . . r)$ possible markets. Each firm under monopolistic market, Dixit and Stiglitz (1977) tries to maximize their nominal profits by increasing their value-added share of production at time $t(t=1 \ldots \ldots . T)$.

$$
\pi_{i t}^{*}=\operatorname{Max}_{i} \pi\left(\Gamma_{i}, y_{i}\right) \ldots
$$

The vector of market, " $\Gamma_{i}$ ", and production $y_{i}$ affect the expected nominal profits in opposite directions, as expansion in market size will normalize profits, while an increase in production with monopoly power will lead to an increase in profits. As market share in Eq. 2 expresses the role of capital, labor, and general price levels, 
the first two terms have a direct relationship to market size and are inversely related to the price factor.

Similarly, the first two factors of the production function (Eq. 3) correspond to that in Marshall (1920) and Porter (1990), where an increase in the regional market size helps the specific region to specialize and improve their factor productivity; and an increase in export volume further boosts their profits. The third factor in Eq. 3, import of final product, negatively affects the regional profit level. Alternatively, $\Gamma_{i}$ affects value-added production in region $i$ by the expected ratio of local factor productivity and the current inflation ratio. Furthermore, the expansion of the regional market and a positive trade balance increases the agglomeration power of the region. Therefore, optimum regional market size $\Gamma_{i}^{*}$ includes measures based on the empirical studies mentioned and reviewed in the previous section.

$$
\begin{aligned}
\Gamma_{i}^{*} & =F\left(\lambda_{i}, \mathcal{L}_{i}, p_{i}\right) \ldots \\
y_{i}^{*} & =F\left(\Gamma_{i}, V_{X i}, V_{M i}, \varnothing_{i}\right) \ldots
\end{aligned}
$$

According to Krugman (1991) and Brakman et al. (2012), the optimum regional market share $\Gamma_{i}^{*}$ of a region " $i$ " at time " $t$ " is directly related to rent to capital " $\lambda_{i t}$ " and wages to labor " $\mathcal{L}_{i t}$ " in the concerned region. The expansion in the market share (through increase in the value-added production) increases market price $p_{i}$. We assume that the agglomeration affects factor productivities, and further changes rent to capital and wages to labor Duranton and Puga (2000). Therefore, any decrease in production costs encourages manufacturers to increase valueadded production. Lower production costs and higher nominal profits attract new firms, which results in a bid for rent and wages until the expected nominal profits from new entrant firms are reduced back to the equilibrium level of factor costs. This phenomenon suggests that wages and rents are dependent on the level of regional agglomeration. Similarly, Shapiro (2006) found that both wages and rent are directly related to the level of regional amenities and access to regional productive externalities. Combining the factors in Eq. 2 helps us formulate the required regression to estimate the magnitude of the concerned factor:

$$
\Gamma_{i t}=\eta_{i}+\eta_{1_{i t}} \mathcal{L}_{i t}+\eta_{2_{i t}} \lambda_{i t}+\eta_{3_{i t}} p_{i t}+\epsilon_{i t}, \ldots
$$

where $\epsilon_{i t}$ is the summation of stochastic error term. Because China and Pakistan have economic ties, the process of finding the aggregate share of each factor to valueadded production by both countries will help us analyze their economic positions. However, this still cannot account for to what extent variation in one or more factors in one country will alter the dimensions of the market share effects in the other country; therefore, substituting Eq. 4 in Eq. 1, we arrive at Eq. 5, which accommodates all the concerned variables. We assume that each region utilizes both labor and capital as a baseline specification and determines the volume of regional value-added production $\left(y_{i t}\right)$. Under the condition $y_{i t}^{*}=\pi_{i t}^{*}$ :

$$
y_{i t}=\zeta_{i}+\zeta_{1_{i t}} \Gamma_{i t}+\zeta_{2_{i t}} V_{X i t}+\zeta_{3_{i t}} V_{M i t}+\zeta_{4_{i t}} \varnothing_{i t}+\epsilon_{i t} \ldots
$$

where value-added production " $y$ " is dependent on regional market share, export " $V_{X i} "$ and import " $V_{M i}$ " volumes of value-added, and foreign direct investment " $\varnothing_{i t}$ ". Each 
new firm-entrant at time " $t$ " chooses one of the available potential " $i$ th" regions, while comparing anticipated profitability. One new firm-entry increases the regional valueadded production by the ratio of its productivity. It also increases regional aggregate value-added production, which, as mentioned previously, stands as the availability of different bundles of goods at cheaper prices, which helps increase the level of regional amenities and further results in an increase in migration of labor (and capital) to the specific region and increase their factor productivities (Marshall 1920). A summary of the variables included in Eq. 5 are presented in Table 1, representing results for each country. The aggregate of each variable, for both countries, is equal to 1 ; by repeating the same procedure will result into the share of certain variables for the specific country throughout the time period. Therefore, the computed mean for each variable is constant while the standard error demonstrates how the two-panel dataset varies. China has greater standard error, for most of the variables, as compared to the case of Pakistan, except for foreign direct investment, value-added imports, and consumer price index, Malik (2015) and Mehmood and Hassan (2015).

\section{Results}

The parameters chosen to test the theoretical model developed in previous section and their significance levels, in term of China and Pakistan are presented in Tables 2 and 3. Following the GLS method, regression simulations are conducted for each country in terms of market effect and value-added production. Each regression result is tabulated and divided into four parts by deleting and including other factors to observe the impact of each regressors on a given regressant more clearly.

Table 2 elaborates the importance of value-added production and sales versus bilateral economic relations on the local market. Column (iv) and column (viii) contains the estimation results in term of local market for China and Pakistan, respectively. Although the two countries have different levels of economic development, both columns show factors as highly significant, due to their economic policies. The two countries have an excess of population and an over-burdened labor force on the local economy, which results in negatively significance of labor to the local market for each country. Likewise, in the case of Foreign Direct Investment

Table 1 Summary statistics of Key variables in China and Pakistan

\begin{tabular}{|c|c|c|c|c|c|c|c|c|}
\hline & \multicolumn{4}{|l|}{ China } & \multicolumn{4}{|c|}{ Pakistan } \\
\hline & Mean & $\begin{array}{l}\text { Std. } \\
\text { Dev. }\end{array}$ & Min. & Max. & Mean & $\begin{array}{l}\text { Std. } \\
\text { Dev. }\end{array}$ & Min. & Max. \\
\hline$y_{i}$ : Industrial value-added & .048 & .049 & .009 & .119 & .048 & .022 & .023 & .083 \\
\hline$\Gamma_{i}:$ Market share & .048 & .042 & .009 & .131 & .048 & .025 & .022 & .096 \\
\hline$\lambda_{j}$ : Ratio of gross capital formation & .048 & .045 & .008 & .139 & .048 & .022 & .021 & .088 \\
\hline $\mathcal{L}_{i}$ : Ratio of labor utilized in value-added production & .048 & .021 & .021 & .079 & .048 & .013 & .029 & .071 \\
\hline$\varphi_{i}$ : Ratio of Foreign direct investment inflow & .048 & .035 & .013 & .106 & .048 & .045 & .009 & .161 \\
\hline$V_{x i}$ value-added exports & .048 & .046 & .003 & .154 & .048 & .036 & .009 & .117 \\
\hline$V_{\text {Mi: }}$ Value-added Imports & .048 & .039 & .009 & .127 & .048 & .045 & .003 & .149 \\
\hline$p_{i}$ : Consumer Price index & .048 & .009 & .032 & .063 & .048 & .025 & .020 & .096 \\
\hline
\end{tabular}

$y$ stands for industrial value-added share, $\Gamma$ for market share, $\lambda$ for capital share, $\mathcal{L}$ for labor share, $v_{x}, V_{M}$ represent valueadded export and import, respectively. $\phi$ explains the volume of foreign direct investment and $p$ stands for consumer price index. 


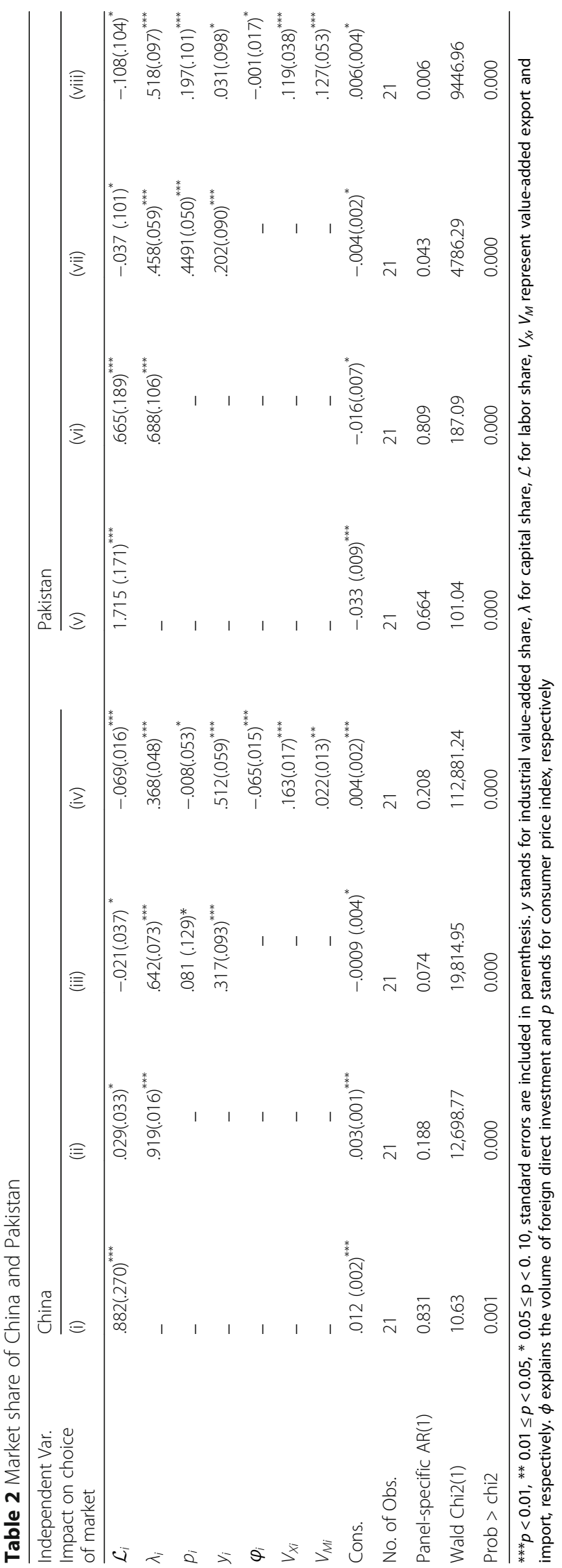




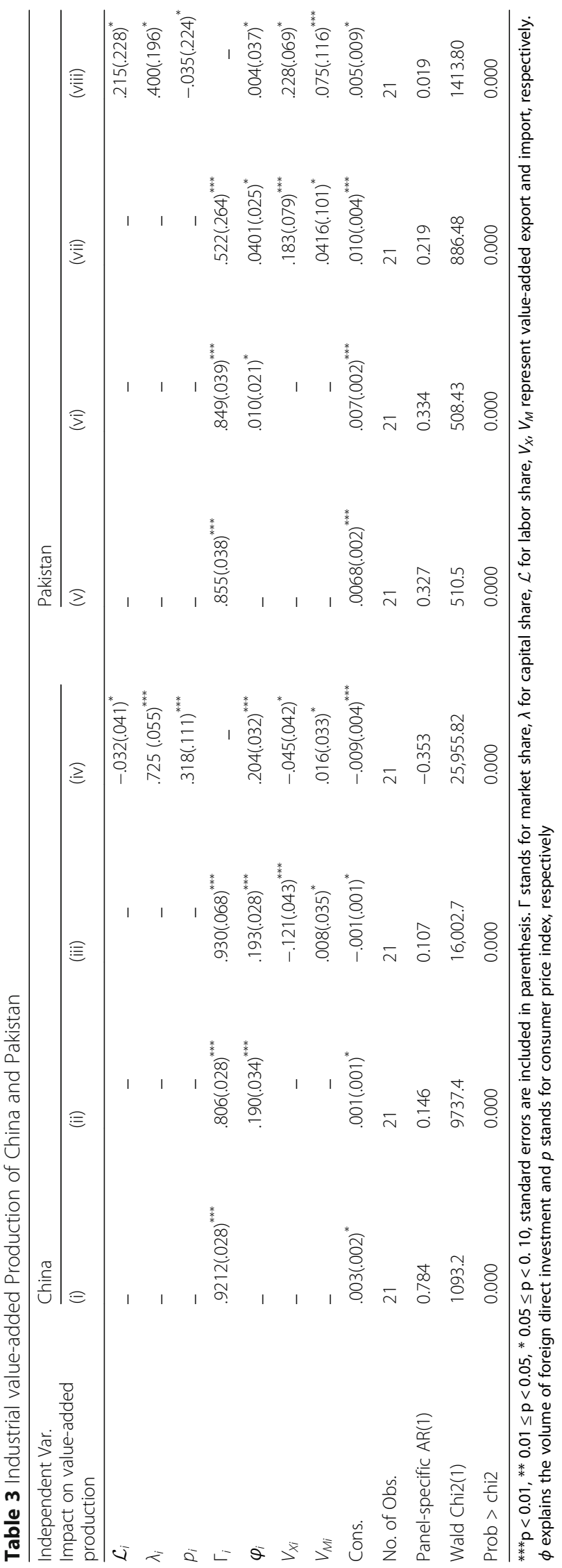


(FDI) influx, the Chinese aggregate market is being negatively affected, whereas the Pakistani market Suleman and Amin (2015), while also reacting similarly to FDI, is significantly less impact than China's. By excluding bilateral economic relations and FDI, column (iii) and column (vii) shows that the adverse effect of national labor has declined; whereas, in term of China, has increased the importance of gross capital formation affirming Hanson (2005). The importance of local value-added production has a positive significant effect on the local market in both countries. Furthermore, by removing CPI and local value-added production, we found that labor and capital effects on the local market has turned positively significant Safdar (2006), as seen in columns (ii) and (vi); whereas comparatively, these factors of production play a central role in forming the local market in Pakistan. The constant factor continuously shows a negative effect on the Pakistani market while it remains positive for China. ${ }^{2}$

Fujita and Thisse (2002) contended that large markets attract more firms and industries and ultimately increase the size of regional markets; similarly, results for both Chinese and Pakistani markets support extension in the value-added production. Meanwhile, their mutual trade in value-added export and import, as reflected through their results, will help extend their markets beyond their boundaries, (Hanson2005; Brakman et al. 2012; Ellison et al. 2010). Results related to market share expansion in market size is beneficial to Pakistan, because of the response of labor, capital accumulation, vector of consumer price, and foreign direct investment. Thus, as found by Imran et al. (2017), these factors are less effective in terms of China to equalize regional economic imbalances.

Statement 1: From the above analysis, it is observed that, being the world's first (China) and sixth (Pakistan) most populous countries, the overburdened labor force, with or without bilateral economic relations, negatively affect the market in each country. However, factors included in the regression apparently show more favorable results for China, as is evident from columns (iii) and (vii). While having bilateral economic relations has more favorable results in terms of Pakistan's market, as reflected in column (iv) and column (viii).

Another central focus of this research is to find the factors included in regression (5) that impact value-added production. Table 3 presents the regression results in term of value-added production, as column (iv) contains results for China and column (viii) for Pakistan. Most of the results are highly significant and affect the regressant. When market effect factors are included, the labor force in China has a negatively significant effect, whereas, that in Pakistan has a positive and significant effect on the country's industrial value-added. Because of the excess of population and heavy pressure on the manufacturing sector, China has failed to fully utilize its labor force and generates a potential spillover effects, as noted by Redding and Venables (2004). In contrast, being a less populated country, Pakistan enjoys the spillover effect from labor. Gross capital formation in China has a greater effect on Chinese value-added production than in Pakistan, which indicates that Pakistan had a persistent capital scarcity. Additionally, Pakistan value-added production is facing inflationary pressures from the price index, while scarce FDI

${ }^{2}$ See Delgado et al. (2010) and Pekkala (2002). 
influx has also proved an obstacle and has the lowest impact on industrial valueadded. Value-added export has played a more important role in Pakistan's valueadded production than China's. Therefore, bilateral economic relations between the two countries are more beneficial for Pakistan than for China.

By affirming labor and capital usefulness in Pakistan, as Duranton and Puga (2004) noted, it is more beneficial to form Economic Zones in Pakistan and accelerate the speed of agglomeration to boost the spillover effect. Through a positive economic relationship with China, Pakistan can attract the establishment of new firms by strengthening the so-called "home-market effect" (Davis and Weinstein 2003; Hanson and Song 1998).

By deleting factors of production and price as expressed in columns (iii) and (vii), the Chinese market and FDI had played a greater role in determining the value-added production in China than in Pakistan. In contrast, bilateral trade relations are better for Pakistan than for China. Under the condition of zero trade between the two countries, market has almost equal effects on the value-added production for both countries; whereas FDI plays a more important role for China. Similarly, under zero trade and no FDI influx, the market effect on Chinese value-added production increases more than in Pakistan.

\section{Comparison}

After going through the simulation and results, this paper tried to analyze and compare the shares made by the two countries to the concerned bilateral ties. The volume of value-added production is different from each other: China enjoys comparatively denser markets with larger value-added production than Pakistan. To analyze the specified comparative advantage, this study utilized Martin and Rogers (1995), who examines whether migration of labor to denser (cheaper) markets lead industries to shift (demand-linked circular casualty) or whether a larger number of producers increase regional market competition in selling firms' products; ultimately, both theories results in a fall in production because of higher production costs (market-crowding effect).

To assess the comparative market structures and remove the nominal terms, this study has tried to compare both the economies as Fig. 1 reflects the value-added

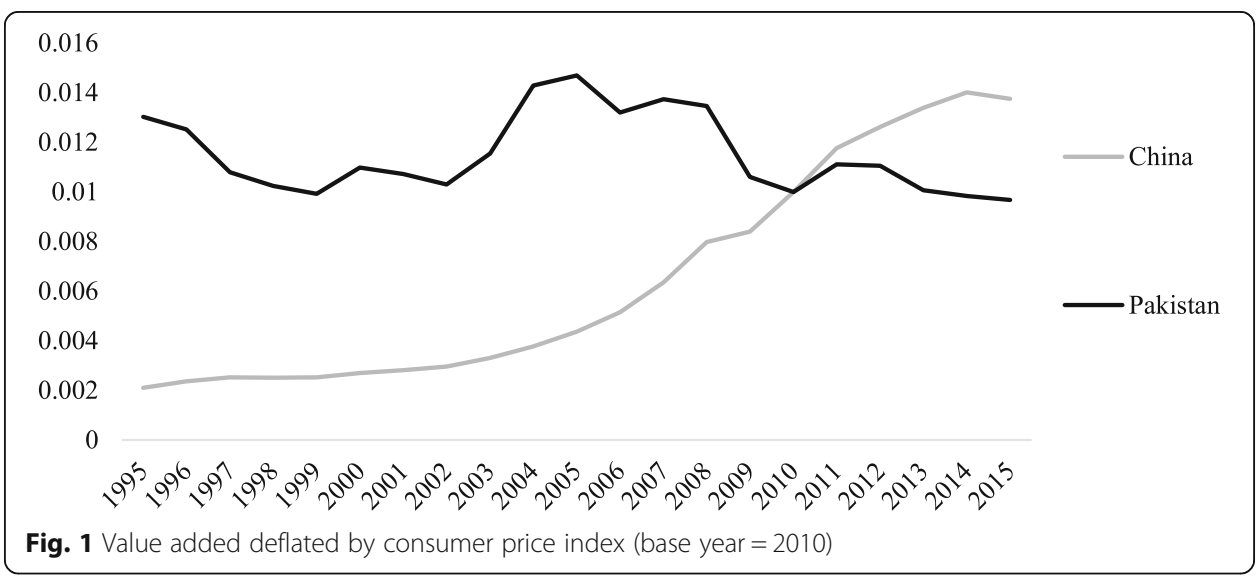


production deflated by the concerned country's consumer price index from 1995 to 2015. Both China and Pakistan show an inverse trend: the change in consumer prices is lower than the change in value-added production of manufacturing sector for China; inversely, the ratio of value-added to consumer price index is falling in Pakistan. ${ }^{3}$ Throughout the paper, deep-dark curves represent China's economy, and shaded curves represent Pakistan's economy. The overall scenario presented in Fig. 1 shows that the change in price is lower than change in value-added for China but begins falling to the right of its tail, which proves that the change in prices are increasing Zhang and Zhuang (2011). The economy of Pakistan shows inverse trends both in value-added production and consumer prices: the annual change in value-added production is lower than the change in prices.

Statement 2: Therefore, higher consumer prices with lower regional value-added production attract new investors to enter the concerned market, which further helps the concerned country to maximize its profits.

Both countries present different market scenarios, one highly competitive, lower consumer prices, and more value-added production with higher production costs (China), and the latter is a perfectly inverse scenario of the former. To analyze further, we examine the trade between two countries, where China's exports to Pakistan are comparatively larger than vice versa, as explained in Fig. 2. Trade across borders follows trade barriers in terms of taxes and policy restrictions that limit the flow of goods.

An increase in the value-added production is a possible solution to overcome trade barriers. Ratios of labor are different in both countries; therefore, Fig. 3 analyzes the growth in labor productivity in terms of value-added production for both countries which is further shown in Fig. 3.

Figure 4 shows the share of labor to value-added production not corrected for bilateral trade (deep-dark curve for China and shaded curve for Pakistan) and share of labor to the value-added production corrected for bilateral trade (the dashed curves with their respective colors). ${ }^{4}$ Fig. 4 shows that China's share of labor to the value-added production is much higher than that of Pakistan throughout the time as expressed through solid curves with their respective colors for both countries. As evident from the shape of the dashed curves, with the passage of time, the comparative share of labor to the trade of value-added started moving in opposite directions for both countries, whereas the share of labor to the trade of value-added by China is higher than Pakistan till 2003 (which is also the least productive year for China) and hovers till 2008. The same pattern is repeated from 2012 to 2014.

Statement 3: The value-added share of Pakistan to the bilateral trade is lower than China; however, after correcting the value-added shares of both countries for their concerned labor productivities, astonishingly, their shares move cyclically and intersect at different times.

\footnotetext{
${ }^{3}$ Ratio of change in value-added of the manufacturing sector to the change in consumer prices based on year 2010.

${ }^{4}$ Labor share to the value-added production not corrected for trade simply calculates the ratio of comparative value-added production to the share of labor to the value-added manufacturing sector, whereas labor share to the value-added manufacturing sector corrected for trade subtracts the ratio of labor growth to the balance of payment, from the share of labor to the value-added manufacturing sector not corrected for trade.
} 


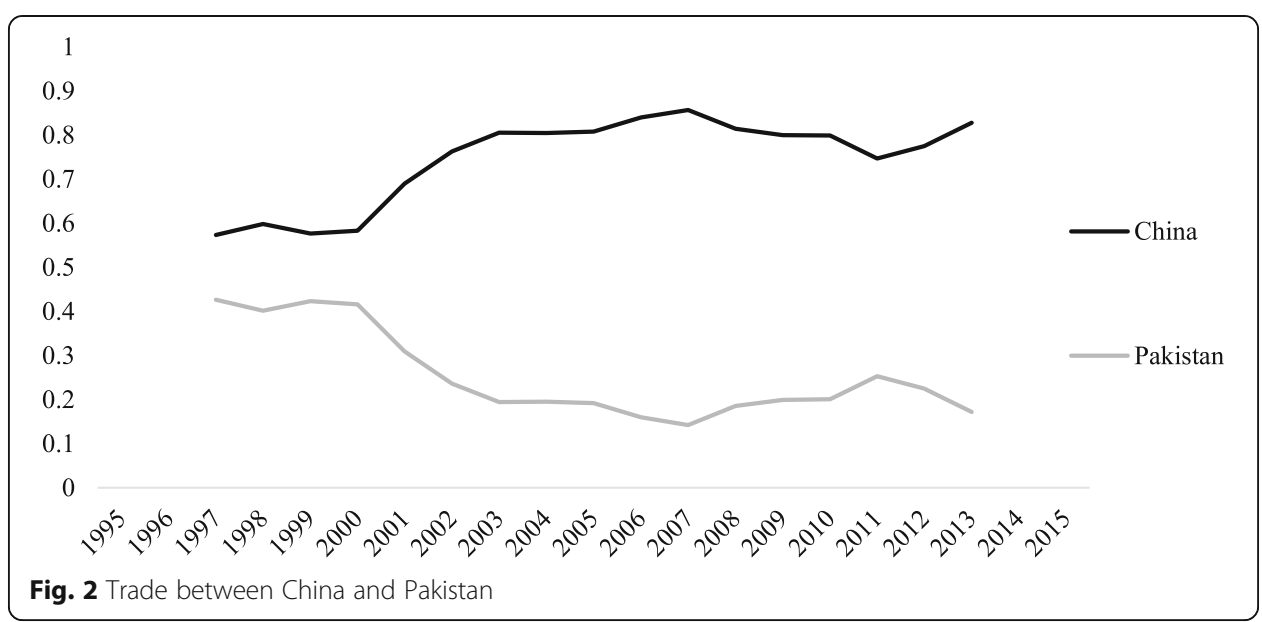

\section{Conclusion}

The distribution of value-added manufacturing sector across regions has prompted the interest of many economists where several factors are identified as the puller of economic activities (see Krugman 1991; Behrens et al. 2009; Baldwin and Okubo 2009). Trade blocs and economic ties provide engine-oil to stimulate such forces either to increase flow of goods or dominate agglomerative powers of a region (or market) over opponent regions, according to Hanson and Song (1998) for NAFTA and Davis and Weinstein (2003) for OECD countries. However, this study addresses Sino-Pak economic ties. Value-added productions of both countries are deflated by the concerned country's consumer price index: the value-added share of Pakistan is more exposed to the CPI, whereas growth in price ratios of Pakistan is much higher than that of China (Fig. 1). While the higher production of value-added products in China are less effected by national consumer prices, conversely, lower consumer prices increase export volumes of Chinese value-added to Pakistani markets (Fig. 3), Lee and Oh (2015). Therefore, China's exports to Pakistan are much higher than Pakistan's export to China. The ratio of labor share to the trade is almost the same. Furthermore, under the same ratio of labor, China's exports share to bilateral trade is much higher than Pakistan's share, meaning that Chinese labor is more productive in the bilateral trade between both

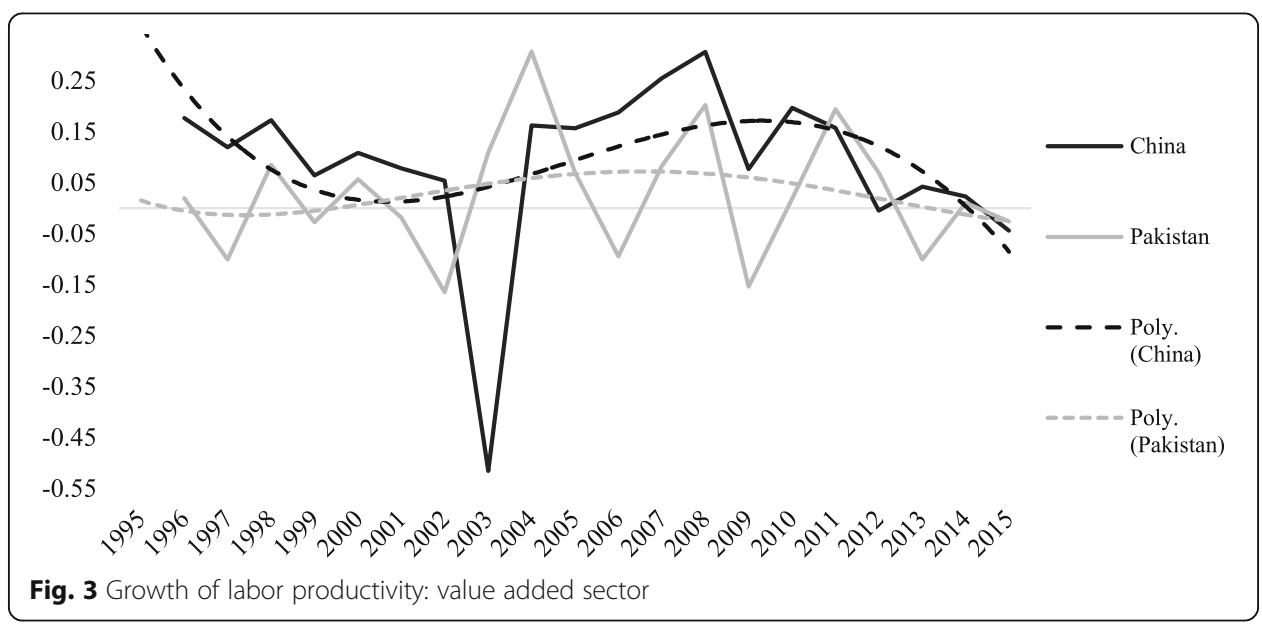




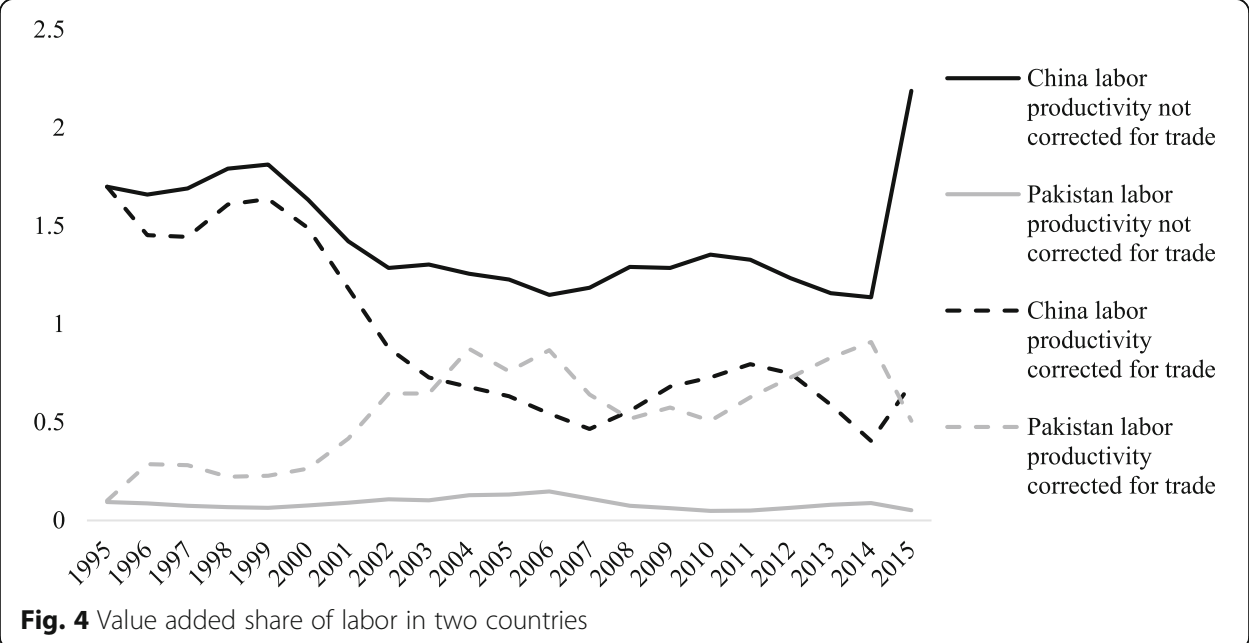

countries (Fig. 4). However, as shown in Fig. 4, the aggregate growth of labor productivity increases, comparatively, at the same ratio for both countries, which means that, by having economic ties, Pakistan's labor will become more productive, both in aggregate production and bilateral trade.

Chinese labor is negatively significant to the concerned countries' market and value-added production, while gross-capital formation is, comparatively, more beneficial for China in both cases. Labor, capital, and FDI perform similar roles in terms of market and value-added production of Pakistan. Other factors such as value-added production and bilateral trade (exports and imports) are important for both nations; although their weightage may vary. Higher prices positively affect market structure in Pakistan and negatively in China. Except consumer price index, all the other included determinants are positively significant to the value-added production in Pakistan. Surprisingly, excess labor, exports, and constant factor are negatively significant in China.

Additionally, the two countries continue to face intraregional and interregional obstacles (e.g., economic issues concerning funds and investment, social issues concerning loss of historical heritages and cultural values, security issues concerning borders and safety of transport, threat to nature concerning loss of forests and safe shelter for animals) that hamper the completion of "China-Pakistan Economic Corridor" project. Apparently, CPEC provides a huge influx of foreign investments to the Pakistani economy that will increase the share of industrial value-added, but further research is required to explain whether these factors play a causal role.

\section{Factor utilization and economic stability}

The economy of Pakistan persistently faces an alarming rate of inflation which has brought evil to the nation in the form of mismanagement at every stage of life, low standards of living, cut-throat competition, corruption, and extremely high crime rates. Therefore, the country has to control its inflation rate because this in turn will have less effects on value-added production both in the sales and purchase forms. Controlled inflation rate will attract more producers and raise the nation's aggregate value-added 
production. The excess amount of production will help the nation bridge the gap between import and export relationships with China. Furthermore, labor should be provided with proper training, and new labor policies should be introduced to encourage labor productivity in both nations, especially in Pakistan.

Whereas in China, new policies should be introduced to safeguard both domestic and foreign investments because capital is comparatively more beneficial for China than labor. However, the aggregate growth of labor productivity in China is on the decline compared to Pakistan. Therefore, the country has to survey the labor community and raise the level of labor productivity as well because China has the world's largest population. Ignoring labor will invite more severe problems to the country in the forms of low standards of living, higher crime rates, rampant corruption, and many other social issues.

\title{
Supplementary information
}

Supplementary information accompanies this paper at https://doi.org/10.1186/s40854-019-0163-z.

Additional file 1. Supplementary material

\section{Acknowledgements}

The author acknowledges Mr. Shahab Khan (Master in Financial Economics) working at the National Bank of Pakistan for his valuable comments and suggestions.

\begin{abstract}
Authors' contribution
The idea of current paper was first presented by Dr. An Husen (PhD supervisor of Dr. Muhammad Imran) that latter Dr. Muhammad Imran started to write this paper with the help of the remaining co-authors he accomplished his task. Dr. Muhammad Kaleem and Dr. Arshad Khan Bangash appreciated the idea and helped in drafting and, particularly, revising the manuscript where they put forward several modifications and amendments at different stages of the manuscript. Mr. Nizam Ud Din and Ms. Sobia helped in data management and approving the results. All authors read and approved the final manuscript.
\end{abstract}

Funding

Not applicable.

Availability of data and materials

The article does not include any kind of unauthorized, restricted, and illegal material and data.

Competing interests

The author(s) declare(s) that they have no competing interests (both financial and non-financial).

\section{Author details}

${ }^{1}$ Department of Economics, Bacha Khan University, Charsadda, Pakistan. ${ }^{2}$ School of Economics, Nankai Universit, Tianjin, China. ${ }^{3}$ Department of Sociology and Gender Studies, Bacha Khan University, Charsadda, Pakistan. ${ }^{4}$ Department of Business Administration, Karakoram International University, Gilgit, Pakistan. ${ }^{5}$ Government Postgraduate Jahanzeb College, Swat, Pakistan.

Received: 18 June 2018 Accepted: 20 November 2019

Published online: 14 January 2020

\section{References}

Baldwin R, Okubo T (2009) Tax reform, Delocation and heterogeneous firms. https://doi.org/10.3386/w15109

Behrens K, Lamorgese AR, Ottaviano Gl, Tabuchi T (2009) Beyond the home market effect: market size and specialization in a multi-country world. J Int Econ 79(2):259-265. https://doi.org/10.1016/j.jinteco.2009.08.005

Brakman S, Garretsen H, Van Marrewijk C, Oumer A (2012) The border population effects of EU integration. J Reg Sci 52(1):40-59. https://doi.org/10.1111/j.1467-9787.2011.00752.x

Combes P, Gobillon L (2015) The empirics of agglomeration economies. In: Handbook of regional and urban economics, pp 247-348. https://doi.org/10.1016/b978-0-444-59,517-1.00005-2

Combes P, Duranton G, Gobillon L (2008) Spatial wage disparities: sorting matters! J Urban Econ 63(2):723-742. https://doi. org/10.1016/j.jue.2007.04.004

Davis DR, Weinstein DE (2003) Market access, economic geography and comparative advantage: an empirical test. J Int Econ 59(1):1-23. https://doi.org/10.1016/s0022-1996(02)00088-0

Delgado M, Porter ME, Stern S (2010) Clusters and entrepreneurship. J Econ Geogr 10(4):495-518

Dixit A, Stiglitz J (1977) Monopolistic competition and optimum product diversity. Am Econ Rev 67:297-308 
Duranton G, Puga D (2004) Chapter 48: Micro-foundations of urban agglomeration economies. In: Handbook of regional and urban economics, pp 2063-2117. https://doi.org/10.1016/s1574-0080(04)80005-1

Duranton G, Puga D (2000) Diversity and specialization in cities: why, where and when does it matter? Ind Locat Econ. https://doi.org/10.4337/9781781950746.00014

Ellison G, Glaeser EL, Kerr WR (2010) What causes industry agglomeration? Evidence from coagglomeration patterns. Am Econ Rev 100(3):1195-1213. https://doi.org/10.1257/aer.100.3.1195

Fujita M, Thisse J (2002) Economics of agglomeration. https://doi.org/10.1017/cbo9780511805660

Fujita M, Krugman PR, Venables A (1999) The spatial economy: cities, regions and international trade. MIT Press, Cambridge, MA

Hanson, H, Gordon (2005). Market potential, increasing returns and geographical concentration. Journal of International Economics, 67(1), 1-24. https://doi.org/10.1016/j.jinteco.2004.09.008

Hanson RC, Song MH (1998) Shareholder wealth effects of free trade: U.S. and Mexican stock market response to NAFTA. Int 449 Rev Econ Financ 7(2):209-224.https://doi.org/10.1016/s1059-0560(98)90041-7

Head K, Mayer T, Ries J (2002) On the pervasiveness of home market effects. Economica 69(275):371-390. https://doi.org/10. $1111 / 1468-0335.00289$

Imran et al (2017) Impact of market access and comparative advantage on regional distribution of manufacturing sector. China Finance Econ Rev 5(4). https://doi.org/10.1186/s40589-017-0047-1

Krugman P (1991) Cities in space: three simple models. https://doi.org/10.3386/w3607

Lee S, Oh D (2015) Economic growth and the environment in China: empirical evidence using prefecture level data. China Econ Rev 36:73-85. https://doi.org/10.1016/j.chieco.2015.08.009

Malik K (2015) Impact of foreign direct investment on economic growth of Pakistan. Am J Bus Manag 4(4). https://doi.org/10. $11634 / 216796061504624$

Marc Lanteigne (2008) China's Maritime Security and the "Malacca Dilemma", Asian Security 4(2):143-161

Marshall, A. (1920) Principles of Economics. 8th Edition, Macmillan, London. https://doi.org/10.1007/978-1-137-37526-1

Martin P, Rogers CA (1995) Industrial location and public infrastructure. J Int Econ 39(3-4):335-351.https://doi.org/10.1016/ 0022-1996(95)01376-6

Mehmood KA, Hassan S (2015) A study on mapping out alliance between economic growth and foreign direct investment in Pakistan. Asian Soc Sci 11(15). https://doi.org/10.5539/ass.v11n15p113

Mohl P (2016) Impact on regional economic growth I: evidence from panel data. In: Empirical evidence on the macroeconomic effects of EU Cohesion Policy, pp 37-73. https://doi.org/10.1007/978-3-658-13,852-3_3

Murata Y (2007) Taste heterogeneity and the scale of production: fragmentation, unification, and segmentation. J Urban Econ 62(1):135-160. https://doi.org/10.1016/j.jue.2006.11.005

Ottaviano G, Tabuchi T, Thisse J (2002) Agglomeration and trade revisited. Int Econ Rev 43(2):409-435. https://doi.org/10. 1111/1468-2354.t01-1-00021

Pekkala S (2002) Migration and individual earnings in Finland: a regional perspective. Reg Stud 36(1):13-24. https://doi.org/10. 1080/00343400120099825

Porter, M. E. (1990). "The Competitive Advantage of Nations." Harvard Business Review 68(2). 73-93. https://doi.org/10.1002/ cir.3880010112.

Redding S, Venables AJ (2004) Economic geography and international inequality. J Int Econ 62(1):53-82. https://doi.org/10. 1016/j.jinteco.2003.07.001

Safdar UK (2006) Macro determinants of total factor productivity in Pakistan. SBP Res Bull 2(2):83-401.

Saqib IM, Xin Q, Arshad H (2015) One belt and one road: does China-Pakistan Economic Corridor benefit for Pakistan's economy? J Econ Sustain Dev. 24(6):200-7

Shapiro, J, M. (2006). Smart cities: quality of life, productivity, and the growth effects of human capital. The Review of Economics and Statistics. 88(2):324-335. https://doi.org/10.3386/w11615

Suleman MT, Amin MT (2015) The impact of sectoral foreign direct investment on industrial economic growth of Pakistan. J Manag Sci 2(1):151-165. https://doi.org/10.20547/jms.2014.021/1501101

Zhang C, Zhuang L (2011) The composition of human capital and economic growth: evidence from China using dynamic panel data analysis. China Econ Rev 22(1):165-171. https://doi.org/10.1016/j.chieco.2010.11.001

\section{Publisher's Note}

Springer Nature remains neutral with regard to jurisdictional claims in published maps and institutional affiliations.

\section{Submit your manuscript to a SpringerOpen ${ }^{\circ}$ journal and benefit from:}

- Convenient online submission

- Rigorous peer review

- Open access: articles freely available online

- High visibility within the field

- Retaining the copyright to your article

Submit your next manuscript at $>$ springeropen.com 